Emilia Denkiewicz-Szczepaniak

Uniwersytet Gdański

\title{
Budowa gmachu Poselstwa Norwegii w Warszawie w latach 1946-1949
}

The building an edifice for the Legation of Norway in Warsaw in the years 1946-1949

The building an edifice for the Legation of Norway in Warsaw, in the years 1946 to 1949, remains one of the most important events in the Polish-Norwegian relations that took place after the Second World War. Alfred Danielsen, a Norwegian envoy in Warsaw, was the main initiator and organizer of the project. In sections I and II, we find a short biography of Danielsen. It includes the first major actions - such as purchasing of the burnt-out premises at Chopin Street $2 \mathrm{~A}$ and information about how the building works were started. Another section refers to the problem of adding extra plots of land situated at Chopin Street 4, and the way Danielsen resolved this issue with the Warsaw authorities. The next two sections refer to the building process, implemented according to the Norwegian Building Committee guidelines. Finally, the last section describes the repair works in 1949 and moving of the Legation to its own building.

Key words: Legation of Norway, Warszawa, Polish-Norwegian relations, Alfred Danielsen, 1946-1949

Słowa klucze: Poselstwo Norwegii, Warszawa, stosunki polsko-norweskie, Alfred Danielsen, 1946-1949

\section{Wstęp}

Jedną z najważniejszych spraw w stosunkach między Polską a Norwegią po zakończeniu II wojny światowej była budowa gmachu Poselstwa Norwegii w Warszawie. Osobą, która odegrała kluczową rolę w tej kwestii, był poseł Alfred Danielsen, mianowany na to stanowisko 20 września 1945 roku. Warszawa miała być po raz drugi jego miejscem pracy. Pierwszy jego pobyt w Warszawie, związany z pełnieniem obowiązków na stanowisku chargé d’affaires, miał miejsce w latach 1920-1922. Drugi pobyt w latach 1945-1950 był dla niego i jego pracowników wyjątkowo trudny, bowiem Warszawa leżała w gruzach, a państwo polskie tworzone było w odmiennych warunkach politycznych. 
Niniejszy artykuł został napisany na podstawie archiwaliów proweniencji norweskiej, zgromadzonych w Archiwum Państwowym (Riksarkivet = RA) w Oslo w zespołach akt przesłanych przez Poselstwo Królestwa Norwegii w Warszawie do norweskiego MSZ (Utenriksdepartementet, Arkivmateriale hjemsendt fra Amb./Leg. Warszawa), obejmujących lata 1945-1949. Jest to jedyna, praktycznie w pełni zachowana dokumentacja, która pozwala na dokładne przedstawienie bardzo trudnego zadania, jakim było zbudowanie od podstaw przez państwo norweskie własnej siedziby dyplomatycznej w powojennej Warszawie.

\section{Kim był Alfred Danielsen?}

Alfred Danielsen urodził się 11 listopada 1885 roku w Rydze. Jego ojciec Daniel Danielsen (1850-1917) był właścicielem fabryki w Rydze; matka - Elise Danielsen (1851-1923) z domu Elmberg. W 1909 roku ukończył studia licencjackie w zakresie prawa na Uniwersytecie w Oslo. Rok później został zatrudniony jako adwokat pomocniczy w Oslo i równocześnie doradca do spraw polityki zagranicznej w dzienniku „Verdens Gang”. W latach 1911-1914 pracował najpierw przez trzy lata na stanowisku pełnomocnika sądowego, a w ostatnim roku - adwokata w sądzie w Skien. Jesienią 1914 roku rozpoczął karierę w norweskim MSZ (Utenriksdepartementet = UD). Do 1918 roku pełnił funkcję sekretarza UD tak zwanej drugiej klasy, kiedy w UD było zatrudnionych czterech sekretarzy (Omang 1959: 220), po czym w 1918 roku objął tymczasowo stanowisko sekretarza Poselstwa Norwegii w Berlinie. Rok 1919 spędził na stypendium we Francji, a następnie 16 stycznia 1920 roku został mianowany na stanowisko sekretarza i konsula w Poselstwie Królestwa Norwegii w Warszawie. W tym czasie ( 5 października 1921 r.) ożenił się z Astri Marie Hesselbom (ur. 5 października 1896 r.), z którą miał dwóch synów: Arne (ur. 8 lipca 1922 r.) i Arilda Johana (ur. 22 sierpnia 1928 r.) (Hvem er hvem? 1950: 128). Warto też podkreślić, że posłem nadzwyczajnym i zarazem konsulem generalnym w Polsce, z którym współpracował Danielsen, był wtedy znany przedsiębiorca norweski Samuel Eyde. Obaj panowie przyczynili się do nawiązania dobrych relacji gospodarczych i politycznych z Polską. Eyde utrzymywał też bardzo dobre kontakty z Józefem Piłsudskim (Denkiewicz-Szczepaniak 2005: 51-75). W lutym 1922 roku Danielsen zakończył swe urzędowanie w Warszawie, po czym został zatrudniony na stanowisku szefa sekretariatu w UD. W 1929 roku skierowano go do poselstwa w Moskwie, gdzie przez sześć lat pełnił funkcję radcy. W latach 1935-1943 sprawował stanowisko chargé d’affaires a.i. w Hawanie i równolegle w latach 1935-1938 w Meksyku, po czym od 1943 roku do końca wojny awansował na stanowisko posła w Hawanie i równocześnie na dwóch sąsiednich wyspach: Haiti (w Port-au-Prince) i Puerto Rico (w Ciudad Trujillo). W latach 1945-1950 sprawował ponownie stano- 
wisko posła w Warszawie i równolegle w latach 1947-1948 w Bukareszcie. Od 1950 roku był szefem norweskiej misji wojskowej w Berlinie i Bonn. Zmarł w Kolonii 13 kwietnia1952 roku (Hvem er hvem? 1950: 128).

\section{Pierwsze działania Danielsena w Warszawie}

Alfred Danielsen przyjechał do Warszawy 12 listopada 1945 roku. Tego samego dnia, podczas uroczystej audiencji w Belwederze, złożył listy uwierzytelniające u Bolesława Bieruta i odbył z nim i podsekretarzem stanu z MSZ Zygmuntem Modzelewskim długą rozmowę o aktualnych problemach norweskich i polskich, po czym został zawieziony przez szefa protokołu dyplomatycznego doktora Adama Gubrynowicza do

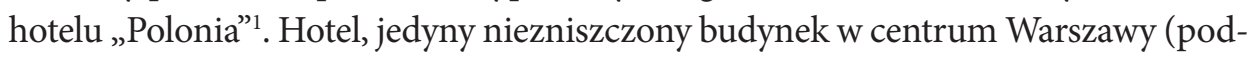
czas wojny był siedzibą Gestapo), mieścił placówki dyplomatyczne wielu państw. Poselstwo Królestwa Norwegii otrzymało w „Polonii” trzy małe pokoje (nr 317, 319 i 320). Dwa z nich stanowily biura, a trzeci był mieszkaniem dla sekretarza Poselstwa. Od samego początku Poselstwo borykało się z różnymi problemami. W hotelu brakowało także lokum dla pracowników, którzy byli zmuszeni szukać mieszkań w zrujnowanej Warszawie. Najbardziej jednak podkreślany problem stanowiły szkodliwe dla zdrowia warunki hotelowe, głównie ze względu na duże problemy z ogrzewaniem i oświetleniem (Denkiewicz-Szczepaniak 2012: 112-113). Nie było też miejsca na postawienie szafy pancernej do przechowywania dokumentów. Odbiło się to między innymi negatywnie na dokumentacji dotyczącej budowy gmachu Poselstwa, bowiem materiały archiwalne $\mathrm{z}$ lat 1946-1947 zaginęly².

Krótką historię tego, co działo się w latach 1946-1947 w kwestii pierwszych decyzji związanych z budową gmachu Poselstwa, odnajdujemy w bezcennym dziewięciostronicowym protokole z pierwszego spotkania komitetu budowlanego w Warszawie w dniu 4 czerwca 1948 roku. W dokumencie tym zacytowano w całości wystąpienie ministra spraw zagranicznych Halvarda Langego w Stortingu 19 lipca 1946 roku, w którym zaprezentował sprawę zakupu domu dla Poselstwa w Warszawie ${ }^{3}$. Z zapisu tego wystąpienia wynika, że kwestia siedziby dla Poselstwa w Warszawie została najpierw poruszona w piśmie Danielsena do UD z 12 lutego 1946 roku, w którym Danielsen opisał bardzo trudne warunki mieszkaniowe

\footnotetext{
${ }^{1}$ Riksarkivet (RA), Utenriksdepartementet (UD), Arkivmateriale hjemsendt fra Amb./Leg. Warszawa, Eske (E) 45, A 7-D 01/45 Sendemann Danielsen, bd. I, pismo Danielsena do UD z 12.11.1945 r.

${ }^{2}$ RA, UD Arkivmateriale hjemsendt fra Amb./Leg. Warszawa - pod spodem notatka o następującej treści: bind. I og bind. II forsvant [tom I i tom II zaginęły - tłum. E.D.-Sz.].

3 Ibid., E. 44, A6-D, bd. III (1948) Legasjons- og konsulathus, protokół z I spotkania komitetu budowlanego w dniu 4.06.1948 r., s. 2-7.
} 
w hotelu „Polonia”, podkreślając zarazem, że ,jedynym rozwiązaniem jest to, aby państwo [norweskie - przyp. E.D.-Sz.] możliwie jak najszybciej wzięło na siebie obowiązek pokrycia kosztów odbudowy jednego z budynków w Warszawie. A jedynym sposobem na zabezpieczenie sobie domu w Warszawie może być tylko to, że lokator sam zapłaci za odbudowanie jednego ze zniszczonych domów"4. Pismo to UD przekazało Ministerstwu Finansów i Ceł, które w odpowiedzi z 21 marca 1946 roku poinformowało, że wydatki z tym związane mogą być pokryte z ministerialnego funduszu hotelowego (Ministerhotellfondet). Dalej Ministerstwo podkreśla, że sprawę tę w dokładniejszej postaci należy przedłożyć Stortingowi, po uprzednim przedstawieniu stanowiska przez UD w kwestii, czy ma to być finansowane z dodatku do budżetu za lata 1945/1946 czy za lata 1946/1947. Z dalszej treści tego protokołu wynika, że Poselstwo zostało upoważnione do sprawdzenia dwóch możliwości: kupna lub wynajęcia budynku. Poselstwo zbadało sprawę nabycia wypalonej posesji przy ul. Chopina 2a w Warszawie i powiadomiło natychmiast Ministerstwo Finansów o możliwości kupna tej posesji. Ministerstwo 15 maja 1946 roku odparło, że nie sprzeciwia się temu, jednakże w tych wyjątkowych okolicznościach uważa za stosowne wysłanie do Warszawy przedstawiciela architekta państwowego, który obejrzy tę posesję. UD poprosiło zatem architekta państwowego o wysłanie swego reprezentanta do Warszawy ${ }^{5}$. Sprawa nie cierpiała zwłoki, dlatego od 6 do 13 czerwca 1946 roku przebywał w Warszawie zastępca norweskiego architekta państwowego architekt Sigurd Trøim. Treść jego meldunku z przeglądu posesji na ul. Chopina 2a - kluczowa dla całej sprawy - została zacytowana w całości we wspomnianym wyżej wystąpieniu ministra spraw zagranicznych w Stortingu. W meldunku tym Trøim podaje rozmiary działki: $743 \mathrm{~m}^{2}$, na której część zabudowana to $512 \mathrm{~m}^{2}$, resztę zaś stanowi ogród. Budynek został zniszczony przez pożar, z którego ocalały jedynie mury zewnętrzne i żelbetonowe belki nośne, natomiast drewniany dach i schody, a także drewniany schron zostały całkowicie zniszczone. W opinii architekta w najlepszym stanie była piwnica o wysokości 2,75 m, w której uszkodzeniu uległy tylko okna, natomiast reszta dzięki grubym murom była w dobrym stanie. Nadto nie została zniszczona instalacja wodno-kanalizacyjna, gazowa i elektryczna. Architekt zakładał, że po wstawieniu nowych belek nośnych ocalałe mury mogłyby pozostać. Dodał też, że władze Biura Odbudowy Stolicy (BOS) zaopatrzyły posesję w szyld, który zakazuje rozbiórki murów, co było powszechną praktyką w pierwszych miesiącach po zakończeniu wojny. Architekt podkreślił również, że bardzo trudno jest kupić w Warszawie dom, co w praktyce oznaczało, że wszystkie wolne nieruchomości można najwyżej wynająć i to pod warunkiem, że wynajmujący sam pokryje koszty naprawy. W praktyce więc czy się chce wynająć, czy kupić jakiś dom, trzeba samemu pokryć

\footnotetext{
${ }^{4}$ Ibid.: 2.

5 Ibid.: 2-3.
} 
koszty jego odbudowy. Poselstwu udało się znaleźć właściciela posesji, stąd kupno stało się realne. Za kupnem tego budynku przemawiało też jego korzystne położenie w Warszawie, w dzielnicy, która przewidziana była na siedziby poselstw obcych państw. Ponadto według planów przestrzennych miasta Warszawy ul. Chopina została włączona w otoczenie Parku Ujazdowskiego, co nie było bez znaczenia dla Norwegów. Z kolei sam budynek i jego przestrzeń wewnętrzna, w tym zwłaszcza duże pomieszczenie na spotkania reprezentacyjne, wraz z garderobą i jadalnią na parterze oraz kuchnią w piwnicy, stwarzały dobre możliwości dla funkcjonowania Poselstwa, oczywiście po gruntownej odbudowie murów. Na pierwszym piętrze architekt proponował wybudować mieszkanie dla posła, na drugim zaś dla reszty personelu. Ostateczna decyzja zapadła, gdy zorientowano się, że cały grunt przeznaczony na poselstwa/ambasady będzie należeć do miasta Warszawy i może być wynajęty na 99 lat za symboliczną opłatą. Wobec powyższego architekt zalecił kupno działki na ul. Chopina 2a dla Poselstwa norweskiego w Warszawie ${ }^{6}$.

W końcowej części cytowanego we wspomnianym protokole z 4 czerwca 1948 roku wystąpienia ministra spraw zagranicznych w Stortingu z 19 lipca 1946 roku znajduje się informacja, że Poselstwo otrzymało od ręki możliwość kupna działki na ul. Chopina 2a, a także zgodnie z decyzją Stortingu z 5 lipca 1946 roku (Stortings innstilling $n r$ 117) norweski MSZ został upoważniony do skorzystania ze środków Ministerhotellfondet w wysokości około 350000 koron norweskich na zakup wymienionej działki i odbudowę wypalonego domu dla potrzeb Poselstwa Norwegii w Warszawie 7 . Jeszcze tego samego dnia (19 lipca 1946 r.) o powyższych postanowieniach zostało poinformowane telegraficznie Poselstwo w Warszawie ${ }^{8}$. W ten sposób pierwszy etap działań Danielsen miał za sobą. W dniu 21 listopada 1946 roku rząd norweski nabył od Felicji Ilony Kiślańskiej (z domu Bąkowskiej, wdowy, zam. w Tarchominie, pow. warszawski) za kwotę 5500000 zł wypaloną nieruchomość w Warszawie przy ul. Chopina 2a, zarejestrowaną w księdze wieczystej pod nr $6172^{9}$.

\section{Sprawa dodatkowej działki na ul. Chopina 4}

Po tych zasadniczych osiągnięciach Danielsen był przekonany, że dalsze działania będą już tylko skoncentrowane na jak najszybszej odbudowie posesji na ul. Chopina 2a. Tymczasem na wiosnę 1947 roku sprawa skomplikowała się, bowiem prezydent Warszawy Stanisław Tołwiński na podstawie przestrzennego planu

\footnotetext{
${ }^{6}$ Ibid.: $4-5$.

7 Ibid.: 5 .

${ }^{8}$ Ibid.

9 RA, E. 44, A 6-D bd. IV (1949) Legasjons- og konsulathus, Utskrift. Register nr 3609/46. Notarialdokument, Oversettelse, s. 1.
} 
zabudowy dla dzielnicy dyplomatycznej przydzielił dodatkowo rządowi norweskiemu podlegającą rozbiórce sąsiednią nieruchomość przy ul. Chopina 4 (o powierzchni $\left.420 \mathrm{~m}^{2}\right)^{10}$. Stworzyło to nie tylko dodatkowe problemy finansowe dla Poselstwa, ale przede wszystkim przedłużyło o kilka miesięcy rozpoczęcie prac na ul. Chopina 2a i miało także wpływ na ich przebieg. Najpierw trzeba było uporać się z przeniesieniem z nieruchomości przy ul. Chopina 4 dziesięciu rodzin, które nie chciały się wyprowadzić bez odszkodowania. Wyprowadzka ta trwała trzy miesiące, co kosztowało Poselstwo 3000 koron norweskich. W sumie więc dopiero w lipcu można było rozpocząć rozbiórkę budynku na ul. Chopina 4, a w sierpniu Danielsen mógł zwrócić się do UD o wydanie upoważnienia na rozpoczęcie prac na ul. Chopina 2a, zgodnie z wcześniej przesłanymi do oceny architektowi państwowemu szkicami. Tymczasem 25 września został telegraficznie upoważniony jedynie do uruchomienia niezbędnych prac zabezpieczających, związanych z wykonaniem pokrycia dachowego na obu wypalonych posesjach, tak by móc te prace ukończyć przed nadejściem zimy. W tej sytuacji Danielsen skupił się na zbadaniu spraw związanych z dodatkową działką na ul. Chopina 4, a zwłaszcza wysokości czynszu rocznego. Wydział Gospodarki Gruntami Miasta Warszawy powiadomił go, że ów czynsz został ustalony na kwotę 290000 zł rocznie, a za podstawę jego obliczenia przyjęto koszt wzniesienia zupełnie nowego budynku, bez uwzględnienia kosztów adaptacji starych murów, uznając, że również resztki murów na ul. Chopina 2a zostaną całkowicie rozebrane. Nadto z podanych przez miasto wyliczeń wynikało, że koszt wzniesienia budynku na obu parcelach przy cenie $5500 \mathrm{zł}$ za $1 \mathrm{~m}^{3}$ wyniesie $40000000 \mathrm{zl}$, a przy podziale według powierzchni parcel koszt części budynku na nieruchomości przy ul. Chopina 4 osiągnie kwotę 14500000 zł. Na tej podstawie dwuprocentowy czynsz za działkę na ul. Chopina 4 ustalono na wspomnianą kwotę 290000 zł rocznie. Czynsz ten Danielsen uznał za zbyt wygórowany, wnosząc o jego obniżenie. W uzasadnieniu dodał, że przy takim wyliczeniu rząd norweski zapłaciłby po osiemdziesięcioletnim okresie trwania czasowej własności 160\% kosztów wzniesienia budynku ${ }^{11}$.

W konsekwencji rozpoczęła się trwająca dwa miesiące korespondencja między Poselstwem a Prezydentem Warszawy. Najpierw 22 stycznia 1948 roku prezydent Warszawy poprosił Danielsena o podanie kosztów związanych z przeprowadzką lokatorów i odgruzowaniem działki na ul. Chopina 4, które Danielsen


wą znacznie ważniejszą dla Danielsena było pozbycie się tej dodatkowej posesji. Opierając się na opinii architektów norweskich, próbował wyjaśnić prezydento-

${ }^{10}$ RA, E. 44, A 6-D bd. III (1948) Legasjons- og konsulathus, notatka ze stycznia 1948 r. wysłana 12 stycznia tegoż roku do prezydenta miasta Warszawy Stanisława Tołwińskiego. ${ }^{11}$ Ibid.

12 Ibid., pismo prezydenta Warszawy z 22.01.1948 r. i odpowiedź Danielsena z 27.01.1948 r. 
wi, że dla Poselstwa działka na ul. Chopina 2a jest zupełnie wystarczająca, podobnie jak przed wojną dla zajmującej ją Ambasady Turcji. Dodał równocześnie, że w razie konieczności Poselstwo może zaakceptować pod zabudowę jedynie połowę z przydzielonej parceli na ul. Chopina 4, czyli $210 \mathrm{~m}^{2}$. W tym samym dniu zwrócił się również do pełnomocnika Poselstwa adwokata Aleksandra Tallena-Wilczewskiego, aby udał się w tej sprawie do Zarządu Miejskiego ${ }^{13}$. W lutym tego roku Danielsen próbował jeszcze raz zawalczyć o zmniejszenie czynszu za parcelę na ul. Chopina 4, ale bez rezultatu. Pismem z 9 marca 1948 roku wyjaśnił też wiceprezydentowi Warszawy Borysowi Jaszczukowi, że Poselstwo przeznacza na odbudowę ul. Chopina 2a około $30 \mathrm{mln}$ zł, a nie $40 \mathrm{mln}$ zł, jak sugeruje miasto, podkreślając równocześnie, że Poselstwo absolutnie nie potrzebuje całej parceli na ul. Chopina 4, a jedynie jej połowę. W odpowiedzi wiceprezydenta Jaszczuka z 19 marca 1948 roku Danielsen otrzymał w zasadzie potwierdzenie dotychczasowego stanowiska władz Warszawy ${ }^{14}$.

W tej sytuacji Danielsenowi nie pozostało nic innego, jak poinformowanie UD o zaistniałych problemach, co uczynił w piśmie z 23 marca, załączając zarazem przetłumaczone na język norweski pismo Jaszczuka z 19 marca. Z treści owego pisma Danielsena do UD wynika, że starał się on zrozumieć stanowisko Warszawy i dlatego sugerował, aby UD zaakceptowało żądania Polaków, mając na uwadze trzy kwestie: bezpieczeństwo poselstwa, względy finansowe związane $\mathrm{z}$ utrzymaniem w ryzach kosztów budowy poselstwa (tj. w wyznaczonej kwocie 350 tys. koron norweskich) i sytuację personelu poselstwa, który nie powinien nadal mieszkać w tak trudnych warunkach. Równocześnie prosi o podjęcie decyzji w sprawie budowy gmachu Poselstwa, ponieważ Przedsiębiorstwo Budowlane inżyniera Mieczysława Wołkowińskiego, odpowiedzialne za całość prac budowlanych, nie powinno dłużej czekać, tym bardziej, że otrzymując wiele ofert, może przenieść się na inną budowę. Ponadto Danielsen prosi UD o decyzję w kwestii, która jeszcze nie została wyjaśniona, a stanowi wymóg władz Warszawy, czyli umieszczenia schronu podziemnego we wszystkich budynkach, również tych publicznych. Stąd w sytuacji przejmowania sąsiedniej posesji na ul. Chopina 4 sugeruje, że ów schron można by dobudować w piwnicy, poszerzając go o trzy metry w kierunku zachodnim na ul. Chopina $4^{15}$.

W kwietniu 1948 roku sytuacja staje się coraz bardziej napięta, bowiem wspomniane przedsiębiorstwo budowlane wciąż nie otrzymywało decyzji w sprawie dalszych prac związanych z wykonywaniem projektu wnętrz, także centralnego

\footnotetext{
${ }^{13}$ Ibid., dwa pisma Danielsena z 6.02.1948 r. do prezydenta Warszawy Tołwińskiego i do mecenasa Aleksandra Tallena-Wilczewskiego.

${ }^{14}$ Ibid., pismo Danielsena z 20.02.1948 r. do prezydenta Warszawy, odpowiedź wiceprezydenta Jaszczuka z 28.02.1948 r., pismo Danielsena do Jaszczuka z 9.03.1948 r. i odpowiedź wiceprezydenta Jaszczuka z 19.03.1948 r.

${ }^{15}$ Ibid., pismo Danielsena do UD nr 128 z 23.03.1948 r.
} 
ogrzewania, wodociągów, kanalizacji itp. Stąd inżynier Wołkowiński zwrócił się dwukrotnie w swych pismach do Poselstwa z prośbą o podjęcie zdecydowanych kroków. W drugim $\mathrm{z}$ tych pism informował, że 14 kwietnia był z wizytą w BOS u inżyniera Józefa Łowińskiego w sprawie ewentualnego zmniejszenia przydzielonej dodatkowo parceli, gdzie ustalił, że można to uczynić, ograniczając jej rozmiary z $420 \mathrm{~m}^{2}$ do $312 \mathrm{~m}^{2}$. Aby móc to przeprowadzić, poprosił Poselstwo o wystosowanie odpowiedniego pisma do Wydziału Planowania BOS (II pawilon na Ujazdowie $)^{16}$. Tymczasem Danielsen był zmuszony czekać na decyzje norweskiego architekta państwowego. Wykonane przez firmę Wołkowińskiego rysunki budynku Poselstwa (z włączeniem części posesji na ul. Chopina 4) wraz z całą dokumentacją przesłane do UD w marcu tegoż roku - mimo wielu jego przypomnień - długo czekały na opinię norweskiego architekta. Dopiero 28 kwietnia UD przesłało odpowiedź architekta Johannesa Thorvaldsena Westby’ego z dnia 23 kwietnia, który stwierdził, że nie zaleca podjęcia zasadniczych prac, zanim nie otrzyma pełnego opisu prac i szczegółowego przeglądu kosztów z nimi związanych wraz $\mathrm{z}$ wyjaśnieniem, na jakich zasadach prace te będą przeprowadzane, to jest kontraktu na określoną kwotę czy też płatności według stawek godzinowych. Ponadto zalecił, podobnie jak to ma miejsce w Norwegii, założenie komitetu budowlanego składającego się z trzech członków: ministra Danielsena, reprezentanta UD i osoby $\mathrm{z}$ Warszawy odpowiedzialnej za całość $\operatorname{prac}^{17}$. Propozycja architekta spotkała się z aprobatą Danielsena, który telegramem przesłanym 1 maja 1948 roku uznał ją za bardzo dobrą. Stąd też szybko udał się do Oslo, gdzie już 11 maja zwołano w UD posiedzenie w następującym składzie: architekt państwowy Westby i jego pracownik architekt Trøim, poseł Danielsen, dyrektor wydziału administracji w UD Aage Bryn, kierownik biura administracyjnego Julius August Christian Fleischer i sekretarz Jens Prøitz ${ }^{18}$. Na posiedzeniu Danielsen przedstawił stan zaawansowania budowy Poselstwa, dając przy tym wyraz trudnościom związanym z uporządkowaniem prawa do dysponowania częścią posesji na ul. Chopina 4. Podkreślał też znaczenie jak najszybszego zakończenia prac budowlanych, sugerując zarazem skoncentrowanie się przede wszystkim na zabudowie działki na ul. Chopina 2a. Architekt Trøim stwierdził brak technicznych przeszkód w realizacji tego celu, ponieważ przedłożone szkice pokazywały, iż „budynek może dobrze funkcjonować, nawet jeśli jego rozszerzenia nie wykona się w pierwszej kolejności. W przypadku bowiem pojawienia się poważnych trudności z walutą, ewentualnie $\mathrm{z}$ warunkami postawionymi przez władze Warszawy w związku z zezwoleniem na zabudowę na ul. Chopina 4, Poselstwo mogłoby przenieść się

${ }^{16}$ Ibid., pisma inż. M. Wołkowińskiego do Poselstwa z 12.04.1948 r. i 14.04.1948 r.

${ }^{17}$ Ibid., pismo UD nr 118 z 28.04.1948 r. wraz z załącznikiem: pismo Riksarkitekta z 23.04.1948 r. do UD odnośnie: Legasjonshuset i Warszawa.

${ }^{18}$ Ibid., protokół z I spotkania komitetu budowlanego w dniu 4.06.1948 r., s. 5-6. 
do pierwszej części budynku zaraz po ukończeniu jego budowy, a dobudowaniem tej drugiej części mogłoby się zająć wówczas, kiedy okoliczności i warunki będą temu sprzyjały. Jeśli ten sposób działania nie będzie podjęty, należy liczyć się z ryzykiem zrealizowania połowy budynku, którego nie będzie można zasiedlić, a także z krytyką braku planowania w tej kwestii” ${ }^{19}$. Niewątpliwie architekt Trøim wykazał się dużą ostrożnością, jednak jego propozycja znalazła odzwierciedlenie w oficjalnym mandacie architekta państwowego Westby'ego z 28 maja 1948 roku, zatwierdzonym przez ministra spraw zagranicznych i poświadczonym przez dyrektora wydziału administracji UD Bryna. W mandacie składającym się z dziewięciu zadań dla komitetu budowlanego znalazły się bowiem praktycznie wszystkie dotychczasowe zalecenia architekta Trøima, uzupełnione jedynie o zbadanie kwestii budowy schronu zgodnie z zaleceniami władz Warszawy. Westby dodał też, że z powodu przeciągającej się sprawy działki na ul. Chopina 4 do Warszawy powinien udać się jak najszybciej jego przedstawiciel architekt Trøim i sekretarz administracji UD Bryn, aby przedyskutować nowe plany ${ }^{20}$. Obaj panowie wyjechali do Warszawy 1 czerwca 1948 roku.

W międzyczasie w kwestii przydzielenia części działki na ul. Chopina 4 skuteczne kroki podjął w urzędzie Warszawy pełnomocnik Poselstwa, wspomniany wyżej adwokat Tallen-Wilczewski. W rezultacie szybko dotarło do Poselstwa pismo prezydenta Warszawy Stanisława Tołwińskiego z 29 maja 1948 roku, w którym informował, że na podstawie opinii adwokata oraz dyrekcji Planowania Przestrzennego BOS wyraził zgodę na przydzielenie na potrzeby Poselstwa Norwegii części działki na ul. Chopina 4, czyli $310 \mathrm{~m}^{2}$ zamiast proponowanych przedtem $420 \mathrm{~m}^{2}$. W dalszej części swego pisma Prezydent podawał wymiary obu działek, których powierzchnia stanowiła w sumie $1040 \mathrm{~m}^{2}$, w tym działka przy ul. Chopina $2 \mathrm{a}-730 \mathrm{~m}^{2}$ i przy ul. Chopina $4-310 \mathrm{~m}^{2}$. Nadto prezydent Warszawy wyliczył, podobnie jak poprzednio, przewidywany koszt wzniesienia budynku na $40 \mathrm{mln}$ zł. Biorąc pod uwagę stosunek rozmiarów obu działek $\left(730 \mathrm{~m}^{2}: 310 \mathrm{~m}^{2}\right)$, koszt zabudowy części nieruchomości na ul. Chopina 4 miał wynieść 11923077 zł. Z sumy tej Zarząd Miejski potrącił kwotę 520000 zł wydatkowaną przez Poselstwo na przekwaterowanie lokatorów. Stąd za podstawę obliczenia czynszu przyjęto kwotę 11403077 zł, z której dwuprocentowy czynsz roczny wynosić miał około 228000 zł. Na koniec prezydent wyjaśnił, że umowa dotycząca własności czasowej będzie zawarta, gdy zostanie uchwalony plan zagospodarowania przestrzennego dla całego obszaru Dzielnicy Ambasad ${ }^{21}$. W ten sposób została ostatecznie rozstrzygnięta sprawa dodatkowej działki na ul. Chopina 4.

${ }^{19}$ Ibid., P.M. av 19. mai 1948: Bygning for den norske legasjon i Warszawa, podpisany przez architekta Sigurda Trøima.

${ }^{20}$ Ibid., Forslag til mandat for byggeutvalget vedrørende legasjonshuset i Warszawa av 28.5.1948.

${ }^{21}$ Ibid., pismo prezydenta Warszawy z 29.05.1948 r. do Poselstwa Norweskiego w Warszawie. 


\section{Posiedzenia komitetu budowlanego w Warszawie w czerwcu 1948 roku}

W dniu 3 czerwca 1948 roku przybyli z Oslo dwaj członkowie komitetu - architekt Trøim i sekretarz z UD Bryn, i jeszcze tego samego dnia dokonali przeglądu dotychczas wykonanych prac. Następnego dnia - 4 czerwca - odbyło się w biurze Poselstwa pierwsze posiedzenie komitetu budowlanego w składzie: poseł Danielsen i dwaj wspomniani panowie z Oslo. Na posiedzeniu tym stwierdzono, że została w pełni odrestaurowana konstrukcja nośna budynku, wstawiono także większość ścianek działowych, a całość konstrukcji zabezpieczono dachem. Danielsen przedłożył omówione wyżej pismo prezydenta Warszawy z dnia 29 maja o zmniejszeniu działki na ul. Chopina 4 do $310 \mathrm{~m}^{2}$, co komitet budowlany przyjął do mandatu swych działań wyznaczonych przez UD. W kwestii pierwszych trzech punktów owego mandatu, czyli opisu prac, przeglądu kosztów i ofert od poszczególnych wykonawców, podkreślono, że firma Wołkowińskiego przedłożyła wykaz wszystkich prac związanych z oczyszczeniem terenu, robotami murarskimi, blacharskimi itp. na ogólną kwotę 12043910 zł wraz z wyszczególnieniem kosztów poszczególnych prac. Komitet uznał przedstawiony opis prac za zadowalający. Ponadto wspomniana firma budowlana obiecała przedstawić jeszcze podczas pobytu komitetu w Warszawie orientacyjny przegląd prac związanych z instalacją grzewczą, sanitarną i elektryczną oraz propozycję wyposażenia wnętrz i prac związanych z fasadą budynku, tak aby komitet mógł od razu odnieść się do tych spraw. W kwestii sposobu płatności za dobry wybór uznano kontrakty z firmami na wykonanie prac za określoną kwotę, gdyż pozwalało to na prowadzenie wielu różnorodnych robót przez mniejsze firmy podwykonawcze. Nowość w mandacie komitetu stanowiło zbadanie sprawy budowy schronu, wymaganego przez przepisy budowlane uchwalone wtedy przez władze Warszawy. Komitet nie miał przygotowanych planów w tej kwestii, ponieważ ten wymóg nie był jeszcze znany w momencie powstawania planów budowy poselstwa. W związku z tym należało się liczyć $\mathrm{z}$ dodatkowymi kosztami. Nadto $\mathrm{w}$ mandacie sugerowano jak najszybsze uruchomienie dalszych prac na ul. Chopina 2a, rozpoczętych jesienią 1947 roku zgodnie z upoważnieniem UD z 8 października 1947 roku. Podjęcie dalszych decyzji - w opinii komitetu - było uzależnione od konsultacji z polskimi władzami i własnych obserwacji komitetu ${ }^{22}$.

Na drugim posiedzeniu w dniu 5 czerwca poza stałym składem (Danielsen, architekt Trøim i sekretarz z UD Bryn) byli obecni zaproszeni na to spotkanie główni polscy wykonawcy: wybitny architekt warszawski, autor projektów wielu ważnych

\footnotetext{
${ }^{22}$ Ibid., protokół z I spotkania komitetu budowlanego w dniu 4.06.1948 r., s. 7-9.
} 
budynków w Warszawie Jan Bogusławski (1910-1982)23 i przedsiębiorca odpowiedzialny za całość prac inżynier Mieczysław Wołkowiński oraz jego współpracownik inżynier Marian Rapacki. Na posiedzeniu tym skupiono się nad projektami architekta Bogusławskiego. Najpierw przedstawił on swoją propozycję odnośnie schronu, także jego wyposażenia, konstrukcji i umieszczenia w zachodniej części budynku, poniżej poziomu piwnicy. Komitet ustalił jednak, że musi przestudiować dokładniej tę propozycję, zanim będzie mógł podjąć ostateczną decyzję. Następnie dyskutowano nad szczegółowymi projektami budowlanymi Bogusławskiego, również dotyczącymi wyposażenia wnętrz i stosowanych materiałów budowlanych. W wyniku tej dyskusji ustalono szereg zaleceń dla polskiego architekta, na przykład wyposażenie całego parteru i piwnicy w kraty żelazne dla zabezpieczenia przed włamaniem, a na pierwszym piętrze wstawienie okien zamiast zaprojektowanych drzwi z sali jadalnej na balkon. Kolejne wskazówki dotyczyły wykończeń zewnętrznych fasad budynku zwykłą zaprawą wapienną z użyciem pewnej ilości kruszonego kamienia dla obramowań okiennych. Ustalono także, że wszystkie podłogi zostaną wykonane $\mathrm{z}$ parkietu dębowego. Nadto ściany $\mathrm{w}$ holu, pokoju przyjęć, małym saloniku i jadalni miały być wyłożone boazerią z drewna jesionowego. Z kolei blaty okienne miały zostać wykonane z jednolitych płyt kamiennych lub innego materiału, który toleruje ciepło płynące od strony kaloryferów. Przed kaloryferami przewidziano ustawienie kratek wykonanych z drewna, tak aby pasowały do ścian pokrytych boazerią drewnianą. Ponadto ustalono, że oświetlenie $\mathrm{w}$ dużym i małym salonie oraz sali jadalnej zostanie umieszczone w gzymsach na ścianach. W dużym i małym salonie oraz w holu na parterze zaplanowano umieszczenie otwartych kominków. Ściany nieobudowane boazerią miały być oczyszczone i pomalowane matową farbą. Drzwi na parterze, a także w salonie gościnnym na pierwszym piętrze zalecono wykonać $\mathrm{z}$ drewna dębowego, ewentualnie jesionowego. Na koniec komitet budowlany stwierdził, że ostateczne stanowisko zajmie wówczas, gdy propozycja architekta zostanie dopracowana w całości ${ }^{24}$.

Trzecie, ostatnie spotkanie komitetu, miało miejsce 7 czerwca. Komitet ponownie zajął się sprawą, która wzbudzała najwięcej kontrowersji, a mianowicie budową schronu. Ostatecznie uzgodniono, że najprostszym rozwiązaniem będzie wykorzystanie do tego celu części istniejącej piwnicy na ul. Chopina 2a, która w zwykłych okolicznościach mogła służyć jako komórka piwniczna do przechowywania na przykład zapasów żywności. Po akceptacji takich założeń zlecono Bogusławskiemu opracowanie szczegółowego projektu schronu. W następnej kolejności przedsiębiorca Wołkowiński przedstawił orientacyjny wykaz

${ }^{23}$ Więcej informacji o Janie Bogusławskim i jego architektonicznych projektach zob. Bogusławski (oprac. 2004); Prof. arch. Jan Andrzej Bogusławski (2014).

${ }^{24}$ RA, E. 44, A 6-D bd. III (1948), Legasjons- og konsulathus. Protokół z II spotkania komitetu budowlanego w dniu 5.06.1948 r., s. 1-2. 
i kosztorys robót wykończeniowych gmachu poselstwa oraz zarys kosztorysu prac instalacyjnych związanych z centralnym ogrzewaniem, wodociągiem i kanalizacją oraz gazem i ciepłą wodą ${ }^{25}$. Z uwagi na krótki termin wykaz ten, zwłaszcza w odniesieniu do prac instalacyjnych, nie był dopracowany do końca, ale - jak podkreślono w sprawozdaniu z tego spotkania - całość projektu dała komitetowi podstawy do stwierdzenia, że prace budowlane będzie można wykonać w ramach tych środków, które ministerstwo postawiło do dyspozycji. Generalnie komitet dobrze ocenił możliwości kontynuacji budowy Poselstwa. Stąd jeszcze tego samego dnia dwaj norwescy członkowie komitetu Bryn i architekt Trøim wyjechali do Oslo ${ }^{26}$.

\section{Przebieg prac w 1948 roku}

Dalszy etap prac to skompletowanie przez firmę Wołkowińskiego całej dokumentacji wspomnianych wyżej instalacji, robót wykończeniowych i budowy schronu. Istotny był $\mathrm{w}$ tym wszystkim sprawny mechanizm działania dopasowany do wymogów komitetu budowlanego. Polegało to na tym, że inżynier Wołkowiński na bieżąco informował pisemnie Poselstwo o wszelkich ustaleniach dotyczących kosztorysów na poszczególne prace, z podaniem nazw firm wykonawczych i ich szczegółowo opracowanych ofert, z których zamierzał skorzystać, dzięki czemu uzyskanie zezwolenia Poselstwa na uruchomienie poszczególnych robót przebiegało szybciej. Należy bowiem podkreślić, że zasadnicze decyzje zapadały w norweskim UD w Oslo, gdzie sprawy nadzorowali wymienieni wyżej członkowie komitetu budowlanego. Gdy Poselstwo otrzymywało od Wołkowińskiego jakąś ofertę wraz z kosztorysem robót, sekretarka Beata Hłasko tłumaczyła ją na język francuski, a następnie przesyłała do Oslo. W sprawach nadzwyczaj pilnych Poselstwo prosiło UD o odpowiedź telegraficzną. O zezwoleniach UD na poszczególne prace Poselstwo powiadamiało Wołkowińskiego na piśmie w języku polskim, oczywiście z udziałem Hłasko. Szczególnie rok 1948 obfitował w korespondencję pomiędzy stronami, bowiem latem i jesienią tego roku Poselstwo chciało zakończyć wszystkie prace, tak aby w grudniu mogło przeprowadzić się do własnego budynku. Zgodnie z wolą Danielsena Wołkowiński działał szybko, bowiem już

\footnotetext{
${ }^{25}$ Ibid., Kosztorys orientacyjny na częściowe roboty wykończeniowe gmachu Poselstwa Królestwa Norwegii, Przedsiębiorstwo Budowlane, inż. M. Wołkowiński, Warszawa, ul. Królewska 29 m 24, Warszawa 6.06.1948 r. W kosztorysie tym za wszystkie wymienione prace wykończeniowe podaje się kwotę 26404500 zł. Ponadto na końcu pisma w języku norweskim zostały odręcznie dopisane niektóre prace instalacyjne wraz z cenami, prawdopodobnie podane ustnie przez Wołkowińskiego, w sumie na kwotę 9870000 zł.

${ }^{26}$ Ibid., protokół z III spotkania komitetu budowlanego w dniu 7.06.1948 r.
} 
26 czerwca 1948 roku przekazał mu wyniki ofert na instalację centralnego ogrzewania, wodociągów i kanalizacji oraz gazu i ciepłej wody. Spośród czterech wymienionych w ofercie firm zaproponował powierzenie robót instalacyjnych firmie Więckowski z ul. Mokotowskiej 29, której oferta była jego zdaniem najkorzystniejsza z uwagi na najniższy całkowity koszt w wysokości 5808440 zł (pozostałe trzy firmy złożyły oferty na kwotę powyżej $6-7 \mathrm{mln}$ zł) ${ }^{27}$. W oddzielnym zestawieniu, $\mathrm{z}$ tą samą datą, przekazał też kosztorys własnej firmy na instalację elektryczną na kwotę $1416420 \mathrm{zk}^{28}$, a dwa dni później na budowę schronu poprzez pogłębienie fundamentów budynku Poselstwa o $30 \mathrm{~cm}$ poniżej projektowanego poziomu piwnicy. Z tym wiązało się, jak podaje, wykonanie ścian żelbetowych o grubości $67 \mathrm{~cm}$, jak również słupów żelbetowych wraz z fundamentami oraz hermetycznie zamykanych okiennic i drzwi. Całość tych prac Wołkowiński wycenił na kwotę $2153454 \mathrm{z}^{29}$. W swoich pismach podkreślał, że wykonanie trwających trzy miesiące prac instalacyjnych jest kluczowe dla szybkiego podjęcia dalszych działań, dlatego oczekiwał na szybką decyzję Poselstwa w sprawie przedstawionych ofert, tak aby prace te można było ukończyć przed nadejściem zimy ${ }^{30}$. $\mathrm{Z}$ dalszych działań firmy Wołkowińskiego wynika, że najbardziej priorytetową sprawą było jak najszybsze wykonanie schronu, tak aby można było podjąć bezpiecznie dalsze prace. Świadczy o tym najlepiej rachunek wystawiony 27 lipca, a więc niespełna miesiąc po złożeniu oferty, w którym zamieszczona jest informacja o wykonaniu zasadniczych robót przy budowie schronu na łączną kwotę $2094684 \mathrm{z1}^{31} .28$ lipca Wołkowiński przekazał też Poselstwu pismo z wynikami ofert na wykonanie prac kamieniarskich, proponując powierzenie robót firmie Granit z ul. Polnej 24 jako najbardziej solidnej, określającej termin wykonania na półtora miesiąca ${ }^{32}$. Ponadto 2 sierpnia przedstawił też wyniki ofert na roboty stolarskie. Wśród podanych pięciu firm wskazał firmę Edwarda Wrzesińskiego z Grochowa (ul. Grenadierów 30), która miała dobrze do tych celów wysuszone drewno i oferowała

${ }^{27}$ Ibid., Wyniki ofert na instalację w gmachu Poselstwa Norweskiego przy ul. Szopena 2a w Warszawie, Przedsiębiorstwo Budowlane inż. M. Wołkowiński, Warszawa, 26.06.1948 r. Pozostałe podane w dokumencie firmy z Warszawy to: Krzyżaniak, ul. Sienkiewicza 4/18, Byliński, ul. Dobra 13 i Piętowski, ul. Widok 22 m 17.

${ }^{28}$ Ibid., Zestawienie kosztorysowe na instalację elektryczną w gmachu Poselstwa Norweskiego w Warszawie, Przedsiębiorstwo Budowlane inż. M. Wołkowiński, Warszawa, 26.06.1948 r.

${ }^{29}$ Ibid., Kosztorys porównawczy na wykonanie schronu (bunkra) w gmachu Poselstwa Norweskiego w Warszawie na poziomie o $30 \mathrm{~cm}$ niżej od poziomu piwnicy, Przedsiębiorstwo Budowlane inż. M. Wołkowiński, Warszawa, 28.06.1948 r.

${ }^{30}$ Ibid., pismo Przedsiębiorstwa Budowlanego inż. M. Wołkowiński do Poselstwa z 7.07.1948 r.

${ }^{31}$ Ibid., rachunek Przedsiębiorstwa Budowlanego inż. M. Wołkowiński dla Poselstwa z 27.07.1948 r.

32 Ibid., Wyniki ofert na roboty kamieniarskie w gmachu Poselstwa Norweskiego przy ul. Szopena 2a w Warszawie z dnia 28.07.1948 r., Przedsiębiorstwo Budowlane inż. M. Wołkowiński. 
szybkie terminy wykonania okien i drzwi (8-18 tygodni) ${ }^{33}$. W dniu 31 lipca odbyła się konferencja $\mathrm{z}$ architektami w Poselstwie, o czym informował pilnie UD chargé d’affaires a.i. Fredrik Eckell. Na tym spotkaniu architekci z przedsiębiorstwa Wołkowińskiego poinformowali, że ceny materiałów budowlanych rosną i dlatego istnieje obawa, że w przesłanych Poselstwu ofertach i zestawieniach kosztów trzeba będzie dokonać korekty, jeśli firmy będą czekać zbyt długo na zezwolenie podjęcia prac. Istniało też ryzyko, że firmy, które złożyły już oferty, mogłyby odmówić ich realizacji z powodu otrzymania innych zamówień. Tłumaczono to dużą liczbą przedsięwzięć budowlanych realizowanych w tym czasie w Warszawie. Architekci podkreślali, że chodzi im zwłaszcza o prace kanalizacyjne i stolarskie. Jako przykład podali ceny parkietu, o których wiedzieli, że za dwa tygodnie wzrosną o $200 \mathrm{zł} \mathrm{za} \mathrm{m²} \mathrm{(z} 1500$ do 1700 zł). Stąd Eckell telegraficznie poinformował UD o tej sprawie, podając, że jeśli w ciągu dwóch tygodni firmy otrzymają zezwolenie na wykonanie prac kanalizacyjnych i stolarskich, będzie można zaoszczędzić $280000 \mathrm{zk}^{34}$. Informacja ta przyniosła szybki i pozytywny odzew, bowiem już 6 sierpnia Eckell zawiadomił Wołkowińskiego o otrzymaniu z UD upoważnienia do wykonania następujących robót: stolarskich, kanalizacji, centralnego ogrzewania, gazu i elektryczności oraz zakupu posadzki dębowej ${ }^{35}$. W ten sposób wszystkie zasadnicze prace instalacyjne mogły rozpocząć się na dobre, a Eckell mógł poinformować UD już 20 sierpnia, że cały budynek będzie wkrótce zadaszony. Niebawem również Poselstwo zawiadomiło Wołkowińskiego, że UD nadesłało upoważnienie na uruchomienie prac kamieniarskich realizowanych przez firmę Granit ${ }^{36}$. Tymczasem na prośbę Danielsena i z jego udziałem zostało zwołane posiedzenie komitetu budowlanego w Oslo, które odbyło się w dniu 15 września. Dyskutowano nad możliwością utrzymania wydatków w wyznaczonej przez UD kwocie 350000 koron. Do dnia 1 lipca 1948 roku wyniosły one ogółem 162500 koron, w tym koszt zakupu działki - 75000 koron norweskich. Po dokonaniu przeglądu wszystkich przedłożonych ofert i po uwzględnieniu wydatków na dodatkowe prace wykończeniowe obaj architekci norwescy stwierdzili, że może dojść jedynie do niewielkiego przekroczenia wyznaczonego budżetu. Danielsen podkreślił zarazem, że chodziło przede wszystkim o ukończenie drugiego piętra, tak aby można było przenieść jak najszybciej biura Poselstwa z hotelu do własnego budynku ${ }^{37}$.

\footnotetext{
${ }^{33}$ Ibid., Wyniki ofert na roboty stolarskie w gmachu Poselstwa Norweskiego przy ul. Szopena 2a w Warszawie z dnia 2.08.1948 r., Przedsiębiorstwo Budowlane inż. M. Wołkowiński.

${ }^{34}$ Ibid., Pismo chargé d’affaires a.i. F. Eckella nr 315 z 31.07.1948 r. do Det Kgl Utenriksdepartementet wraz z 4 załącznikami omówionych wcześniej ofert budowlanych.

${ }^{35}$ Ibid., Pismo chargé d’affaires a.i. F. Eckella z 6.08.1948 r. do Przedsiębiorstwa Budowlanego inż. M. Wołkowiński.

${ }^{36}$ Ibid., pismo F. Eckella do UD z 20.08.1948 r. i pismo Poselstwa do Przedsiębiorstwa Budowlanego inż. M. Wołkowiński z 13.09.1948 r.

37 Ibid., Notat av 16.09.1948 r.
} 
W piśmie do UD z 3 listopada Danielsen informuje, że na jego prośbę Wołkowiński złożył uzupełniony przegląd wszystkich kosztów budowy na łączną kwotę 50818321 zł. Nadto pisze, że polski MSZ i Ministerstwo Przemysłu interweniowały na korzyść Poselstwa w sprawie dostarczenia kotłów grzewczych z Łodzi. Ocenia też pozytywnie zdolności artystyczne polskich architektów i inżynierów zajmujących się wykończeniem fasad i gzymsów budynku, zaś mniej pozytywnie wyraża się o jakości wyposażenia (umywalki, kuchenki gazowe itp. ${ }^{38}$ ). Optymizm Danielsena odnajdujemy w jego piśmie do polskiego MSZ, w którym informuje, że budynek ma być oddany do użytku w ciągu najbliższych trzech tygodni, prosząc zarazem, aby MSZ doprowadził do jak najszybszego założenia wodomierza na posesji przy ul. Chopina 2a przez Dyrekcję Wodociągów i Kanalizacji w Warszawie ${ }^{39}$.

\section{Rok 1949 - prace naprawcze i przeprowadzka do własnego budynku}

Z początkiem grudnia 1948 roku dobra passa w działalności budowlanej przedsiębiorstwa Wołkowińskiego nagle się załamała. Danielsen wyrażał zaniepokojenie brakiem właściwego wykonania robót instalacji centralnego ogrzewania i kanalizacji. Prosił też o definitywne wyznaczenie na piśmie terminu oddania do użytku pomieszczeń biurowych i mieszkalnych na drugim piętrze. W tej ostatniej sprawie Wołkowiński odpowiedział bardzo szybko, deklarując ostateczny termin na 20 stycznia $1949 \mathrm{roku}^{40}$. W kwestii instalacji grzewczej zareagował dopiero na początku stycznia 1949 roku, przekazując Danielsenowi odpis pisma z 7 stycznia 1949 roku skierowanego do odpowiedzialnej za wykonanie tej instalacji firmy Więckowskiego. W piśmie tym wyszczególnił wszystkie błędy i chaos w pracy tej firmy, wskutek czego wiele rur było źle podłączonych, ogrzewanie nie działało, a niewysuszenie pomieszczeń spowodowało obniżenie jakości robót kamieniarskich, murarskich i malarskich ${ }^{41}$. Pismo to posłużyło Danielsenowi jako dowód na spotkaniu norweskiego komitetu budowlanego w Oslo 15 stycznia tegoż roku, na którym stwierdzono, że nieszczęściem było powierzenie prac związanych z ogrzewaniem budynku Więckowskiemu, który jako profesor, specjalista od spraw ka-

\footnotetext{
${ }^{38}$ Ibid., pismo Danielsena do UD z 3.11.1948 r.

39 Ibid., pismo Danielsena do polskiego MSZ z 7.10.1948 r.

${ }^{40}$ Ibid., pisma Danielsena do Przedsiębiorstwa Budowlanego inż. M. Wołkowiński z 6.12.1948 r. i 10.12.1948 r. i odpowiedź Wołkowińskiego z 10.12.1948 r.

${ }^{41}$ RA, E. 44, A6-D, bd. IV (1949), Legasjons- og konsulathus; pismo Przedsiębiorstwa Budowlanego inż. M. Wołkowińskiego do firmy inż. L. Więckowskiego z 7.I.1949 r. Adnotacja odręczna Eckella na końcu pisma: „2 oversettelser medtatt av Min.Danielsen til Oslo 10.I.49” [dwa tłumaczenia zabrał ze sobą do Oslo Min. Danielsen 10.01.49 - tłum. E.D.-Sz.].
} 
nalizacyjno-hydraulicznych, wykorzystywał do robót studentów praktykantów, nie nadzorując ich na budowie, co doprowadziło do szeregu nieprawidłowości. Po wielu ustnych i pisemnych interwencjach w firmie Wołkowińskiego dopiero w marcu tego roku udało się Danielsenowi zerwać kontrakt z firmą Więckowskiego. Poselstwo powołało następnie rzeczoznawcę do spraw urządzeń cieplnych i zdrowotnych, inżyniera Józefa Skubalskiego, który po dokładnym przeglądzie i ocenie dotychczas wykonanych prac polecił Danielsenowi cieszącą się dobrą opinią firmę Drzewieckiego i Jeziorańskiego (Al. Jerozolimskie 35) ${ }^{42}$. Firma ta przystąpiła do przeglądu instalacji grzewczej i wodociągowej na początku kwietnia, a po upływie dwóch miesięcy (21 czerwca) przedstawiła przybliżony koszt robót związanych z naprawą instalacji grzewczej, także wodociągowej i kanalizacyjnej, równocześnie wyjaśniając, że należy zdemontować większość rur wodociągowych i kanalizacyjnych z powodu ich nieodpowiedniej średnicy, zdjąć źle zamontowane grzejniki oraz wstawić nowe krany regulacyjne itp. ${ }^{43} \mathrm{~W}$ kosztorysie tym uwzględnione zostały także koszty urządzenia w piwnicy pralni, suszarni, spiżarni i kuchni, których wykonanie zlecono firmie dodatkowo. Prace związane $\mathrm{z}$ instalacją ogrzewania trwały do początku września, natomiast pozostałe roboty kanalizacyjne do późnej jesieni, co wynikało z braku materiałów i stosownych urządzeń. Główną jednak przyczyną opóźnień był fakt, że firma Wołkowińskiego - podobnie jak wiele innych prywatnych przedsiębiorstw budowlanych w tym czasie - była w stanie likwidacji, o czym Poselstwo zostało poinformowane przez tę firmę pismem z 20 czerwca 1949 roku. Należy tu wyjaśnić, że zgodnie z ustawą KRN z 3 stycznia 1946 roku o nacjonalizacji wszystkich przedsiębiorstw przemysłowych (Ustawa o przejęciu na własność... 1946) - z wyjątkiem budowlanych i instalacyjnych - duże przedsiębiorstwa przemysłowe zostały od razu upaństwowione, natomiast nieobjęte tą ustawą firmy budowlane i instalacyjne funkcjonowały jeszcze 3-4 lata, czego najlepszym dowodem są firmy budujące gmach Poselstwa Królestwa Norwegii. W połowie 1948 roku z pobudek czysto ideologicznych oraz w wyniku dążenia Polskiej Partii Robotniczej do umocnienia swej władzy nastąpił atak na cały sektor prywatnych przedsiębiorstw. W socjalistycznej Polsce, zgodnie $\mathrm{z}$ wytycznymi plenum KC PPR, już w połowie 1948 roku podjęto decyzję o pospiesznej likwidacji wszystkich firm prywatnych. Wobec firm pozostających jeszcze w rękach prywatnych stosowano różnego rodzaju restrykcyjne podatki, czynsze oraz administracyjne kary pieniężne, które miały doprowadzić je do upadku. Nasiliło się to zwłaszcza po kongresie zjednoczeniowym PPR i PPS

\footnotetext{
${ }^{42}$ Ibid., pismo Danielsena nr 119 z 29.03.1949 r. do UD wraz z załączonym doń pięciostronicowym pismem rzeczoznawcy J. Skubalskiego z 9.03.1949 r.

${ }^{43}$ Ibid., trzy pisma Przedsiębiorstwa Urządzeń Zdrowotnych, Drzewiecki i Jeziorański, sp. z o.o., Warszawa, Al. Jerozolimskie 35 z: 2.04.1949 r., 21.06.1949 r. i 22.06.1949 r. W piśmie z 21.06.1949 r. firma określa koszty swych prac na kwotę 4465074 zł.
} 
w grudniu 1948 roku, na którym powstała PZPR - partia komunistyczna podporządkowana całkowicie Związkowi Sowieckiemu. Na jej czele stanął sekretarz generalny Bolesław Bierut, zaś Władysław Gomułka, przeciwnik totalnej nacjonalizacji, został odsunięty na boczny tor. Był to wyraźny zwrot w polityce gospodarczej PRL, prowadzący do zacieśnienia powiązań z gospodarką sowiecką (Skodlarski 2014: 342-348; Morawski 2011: 252-257). W przypadku budowy Poselstwa zmiany były widoczne już na wiosnę 1949 roku. Z dokumentacji archiwalnej wynika, że firma Wołkowińskiego zabiegała wiosną i latem tegoż roku o przeprowadzenie prac związanych z położeniem drewnianej klepki podłogowej, a także z innymi robotami wykończeniowymi, ale nie sprzyjały temu wspomniane wyżej decyzje polityczne nakazujące upaństwowienie wszystkich firm. To z kolei spowodowało ograniczenia w dostępie do materiałów budowlanych, które znalazły się teraz w rękach państwowych i można je było zdobyć jedynie na zasadzie przydziału. Na to wszystko nałożyła się jeszcze sprawa przeciekającego dachu w nowo wybudowanym gmachu Poselstwa, choć w tym przypadku dzięki zapobiegliwości Danielsena udało się ten problem w porę rozwiązać. Przy częściowym wsparciu Wołkowińskiego Danielsen zdążył zatrudnić nieupaństwowioną jeszcze firmę Izolacja z ul. Hożej 55, której przedstawiciele po obejrzeniu pokrycia dachu stwierdzili, że użyta do tego celu papa była zbyt cienka, stąd jej powłoka na skutek działań atmosferycznych została całkowicie uszkodzona. Dzięki zdobyciu przez Wołkowińskiego sześciu rolek papy bitumicznej firma Izolacja zdołała naprawić dach jeszcze latem 1949 roku $^{44}$.

Już od stycznia 1949 roku Danielsen rozpoczął stopniową przeprowadzkę do nowego budynku. Pierwszy transport w dniu 8 stycznia stanowiły meble - szafa i biurko kupione w warszawskim antykwariacie „Arkady”. Następnie Danielsen poinformował Wołkowińskiego, że 17 lutego z rana odbędzie się przeprowadzka biura poselstwa do czterech pokoi na drugim piętrze, stąd prosił, aby w trakcie wnoszenia mebli wstrzymano na ten czas roboty wykończeniowe na klatce schodowej ${ }^{45}$. Miesiąc później, w marcu, wprowadził się do mieszkania na pierwszym piętrze Danielsen z małżonką, a na drugim piętrze oddano do użytku dwa mieszkania dla kancelisty i chargé d’affaires Poselstwa. W kwietniu 1950 roku Danielsen przekazał UD, że adwokat Poselstwa Tallen-Wilczewski poinformował go o potrzebie podania władzom Warszawy terminu objęcia budynku w posiadanie przez

${ }^{44}$ RA, E. 44, A6-D, bd. IV (1949), Legasjons- og konsulathus, pismo firmy Izolacja do kierownictwa robót przy budowie gmachu Poselstwa Norweskiego z 25.IV.1949 r. i pismo Przedsiębiorstwa Budowlanego inż. M. Wołkowiński do Poselstwa z 26.04.1949 r.; RA, E. 45, A6-D, bd. V, Legasjons- og konsulathus, dwa pisma Przedsiębiorstwa Budowlanego inż. M. Wołkowiński do Poselstwa z 7.06.1949 r. i 16.06.1949 r.

${ }^{45}$ Ibid., dwa pisma Danielsena: z 7.01.1949 r. do Przedsiębiorstwa Przewozowego z ul. Hożej 13 i pismo z 14.02.1949 r. do Przedsiębiorstwa Budowlanego inż. M. Wołkowiński. 
Poselstwo. Danielsen po konsultacji z UD zaproponował wyjście pośrednie, stąd jako dzień przeprowadzki podał 1 lipca 1949 roku $^{46}$.

Podsumowując, należy podkreślić, że dzięki sprawnym działaniom posła Danielsena, $w$ tym zwłaszcza dobrym relacjom $\mathrm{z}$ wieloma polskimi firmami budowlanymi, a także z władzami Warszawy, udało się w ciągu trzech lat wybudować gmach Poselstwa na ul. Chopina 2a. Nie bez znaczenia było również to, że już w lutym 1946 roku Danielsen skierował pismo do norweskiego MSZ w tej sprawie, a następnie szybko przystąpił do działań organizacyjnych. Upaństwowienie wszystkich firm, w tym również budowlanych, które rozpoczęło się pod koniec 1948 roku, przyczyniłoby się z pewnością nie tylko do opóźnienia prac, ale również do szeregu administracyjnych perturbacji. To dzięki zapobiegliwości Danielsena i jego ogromnej aktywności w kontaktach z władzami polskimi, norweskim MSZ oraz polskimi firmami budowlanymi na czele z przedsiębiorstwem inżyniera Wołkowińskiego budynek norweskiej placówki dyplomatycznej już od stycznia 1949 roku mógł być stopniowo zasiedlany przez pracowników poselstwa. Należy również podkreślić fakt, że przedstawiona $\mathrm{w}$ artykule sprawa związana $\mathrm{z}$ zakupem posesji i wybudowaniem gmachu Poselstwa na koszt państwa norweskiego była wówczas jedynym takim przypadkiem w Warszawie. Państwu norweskiemu zależało bowiem nie tylko na utrzymaniu placówki dyplomatycznej w Warszawie z uwagi na dobrze zapowiadające się stosunki gospodarcze z Polską, ale również na stworzeniu bezpiecznych warunków jej funkcjonowania w zrujnowanej Warszawie.

Bibliografia

Źródła archiwalne

Riksarkivet Oslo (RA)

Utenriksdepartamentet (UD), Arkivmateriale hjemsendt fra Amb./Leg. Warszawa:

a) E. 44, A 6-D Legasjons- og konsulathus, bd. III (1948)

b) E. 44, A 6-D Legasjons- og konsulathus, bd. IV (1949)

c) E. 45, A 7-D 01/45 Sendemann Danielsen (bd. I).

Utenriksdepartementet (UD) 1950-59, E. 303, 2.21/91 h, Leg. Warszawa. Hus, bd. V 1950-52.

Opracowania

Bogusławski, J. (2004). Jan Bogusławski. Architekt... Culture, http://culture.pl/pl/tworca/jan-boguslawski (dostęp: 30.08.2017).

Prof. arch. Jan Andrzej Bogusławski. (2014). In memoriam. Pamięci architektów polskich, http://www.inmemoriam.architektsarp.pl/pokaz/jan_andrzej_boguslawski,4327 (dostęp: 30.08.2017).

${ }^{46}$ RA, UD 1950-59, E. 303, 2.21/91 h, Leg. Warszawa. Hus, bd. V 1950-52, pismo Danielsena do UD nr 86 z 11.04.1950 r. 
Denkiewicz-Szczepaniak, E. (2005). Stosunki polityczne i gospodarcze Polski z Norwegią w latach 1918-1926. Zapiski Historyczne LXX (2-3): 51-75.

Denkiewicz-Szczepaniak, E. (2012). Polityka wewnętrzna Polski w świetle raportów Poselstwa Królestwa Norwegii w Warszawie z lat 1945-1948. Dzieje Najnowsze XLIV (1): 112-113.

Hvem er hvem? (1950). Oslo: H. Aschehoug \& Co.

Morawski, W. (2011). Dzieje gospodarcze Polski. Warszawa: Difin.

Omang, R. (1959). Norsk utenrikstjeneste. Stormfulle tider 1913-1928. Oslo: Gyldendal Norsk Forlag.

Skodlarski, J. (2014). Historia gospodarcza. Warszawa: Wydawnictwo Naukowe PWN.

Ustawa z dnia 3 stycznia 1946 r. o przejęciu na własność Państwa podstawowych gałęzi gospodarki narodowej (Dz. U. z 1946 r. Nr 3, poz. 17). 